\title{
Lavado Correcto de las Manos para Manipuladores de Productos Frescos ${ }^{1}$
}

Amy Simonne, Mark Ritenour, Jeff Brecht, Steve Sargent, and Keith Schneider ${ }^{2}$
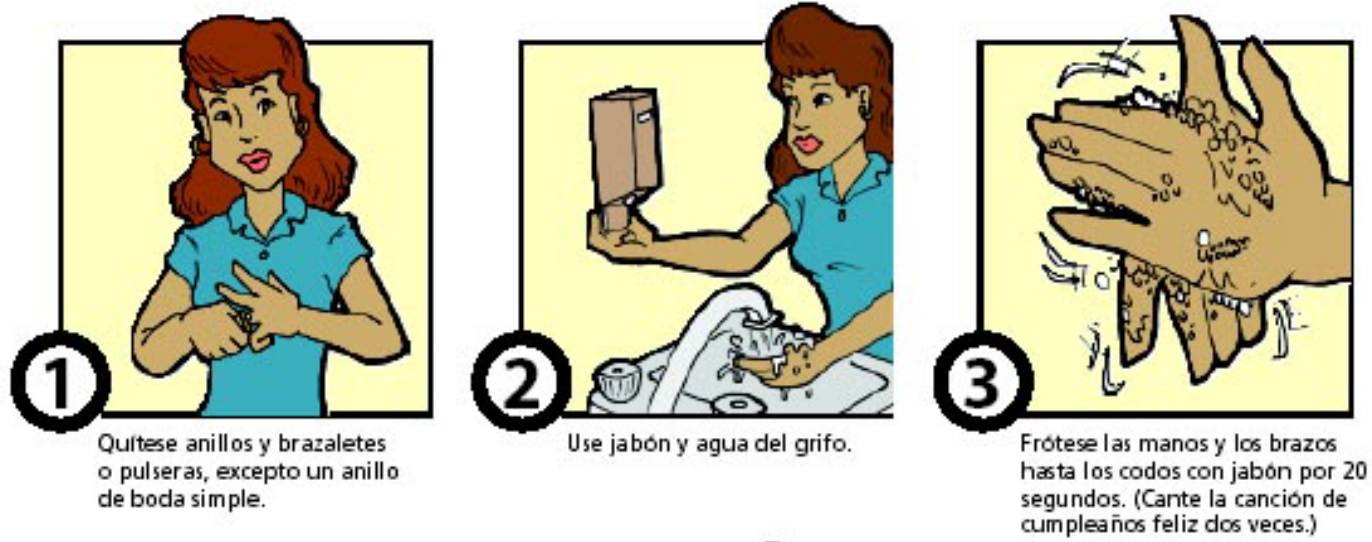

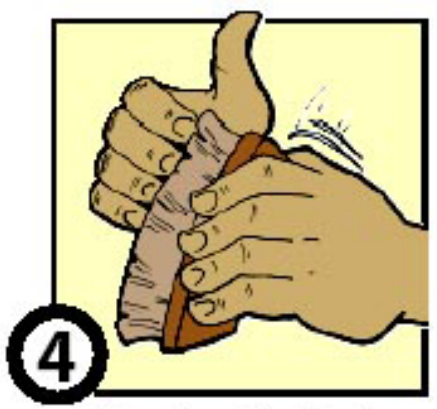

Lávese la parte de atrás de sus manos y las muñecas, entre los dedos y bajo las uñas usando un cepillo.

\section{Lávese las manos antes de:}

- Regresar al campo o incorporarse a la línea de empaquetamiento

- Manipular productos frescos (frutas y vegetales)

- Cambiar los guantes

- Preparar alimentos

- Consumir alimentos

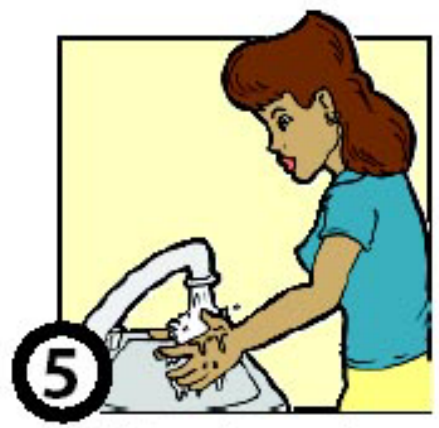

Enjuaguese las manos y los brazos bajo el chorro de agua corriente.

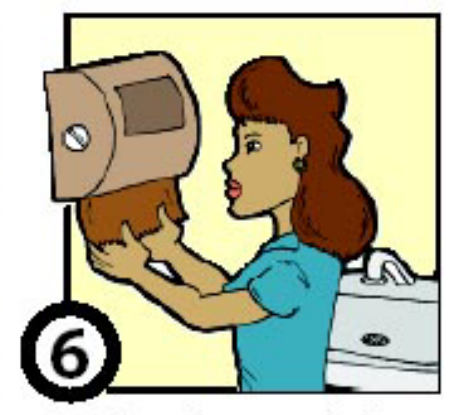

Sequese las manos y los brazos con toallas de papel desechables. Use una toalla de papel para cerrar el grifo.

\section{Lávese las manos después de:}

- Ir al baño

- Tocarse el cuerpo, la cara o el pelo

- Trabajar con tierra o productos frescos (frutas y vegetales) que estén podridos

- Tocar la basura

- Fumar u otras actividades que puedan ensuciar sus manos

1. This document is FCS8762-Span, one of a series of the Department of Family, Youth and Community Sciences, Florida Cooperative Extension Service, IFAS, University of Florida, Gainesville FL 32611. First published: March 2004. Reviewed by Linda B. Bobroff, Ph.D., RD, LD/N, Family, Youth and Community Sciences. Meredith C. Taylor, M.S., FCS, P.L., extension agent IV, Suwannee County. Sally K. Williams, Ph.D., associate professor, Animal Sciences. Institute of Food and Agricultural Sciences, University of Florida, Gainesville, FL 32611. Translated by Sergio Romero. Please visit the EDIS Web site at http://edis.ifas.ufl.edu

2. Amy Simonne, Ph.D., assistant professor, Department of Family, Youth and Community Sciences; Mark Ritenour, Ph.D., assistant professor, Indian River REC; Jeff Brecht, Ph.D., professor and Steve Sargent, Ph.D., professor, Horticultural Sciences Department; and Keith Schneider, Ph.D., assistant professor, Department of Food Science \& Human Nutrition. Cooperative Extension Service, Institute of Food and Agricultural Sciences, University of Florida, Gainesville, FL 32611.

The Institute of Food and Agricultural Sciences is an equal opportunity/affirmative action employer authorized to provide research, educational information and other services only to individuals and institutions that function without regard to race, color, sex, age, handicap or national origin. For information on obtaining other extension publications, contact your county Cooperative Extension Service office. Florida Cooperative Extension Service/Institute of Food and Agricultural Sciences/University of Florida/Christine Taylor Waddill, Dean. 